\title{
THE IMPACT OF THE COVID-19 PANDEMIC AND THE EFFORT OF MSME RESURRECTION IN INDONESIA
}

\author{
by \\ Edy Prayitno', Nerys Lourensius Tarigan², Wahyu Eka Priana Sukmawaty ${ }^{3}$, Uyuunul Mauidzoh ${ }^{4}$, Deborah \\ Kurniawati ${ }^{5}$ \\ ${ }^{1,5}$ STMIK AKAKOM Yogyakarta, Indonesia \\ ${ }^{2}$ STIE IEUpaweda, Yogyakarta, Indonesia \\ ${ }^{3}$ AKS AKK, Yogyakarta, Indonesia \\ ${ }^{4}$ ITDA Yogyakarta, Indonesia \\ Email: ${ }^{1}$ edyprayitno@akakom.ac.id
}

\begin{tabular}{|c|c|}
\hline Article Info & ABSTRACT \\
\hline Article history: & \multirow{5}{*}{$\begin{array}{l}\text { The COVID-19 pandemic has had a negative impact on the global economy, including } \\
\text { Indonesia. The main victims of the COVID-19 outbreak are micro, small and medium } \\
\text { enterprises (MSMEs). This article aims to examine the impact of the Covid-19 } \\
\text { pandemic on MSMEs and provide recommendations that can be done to reduce } \\
\text { business losses, survive the crisis and accelerate recovery. MSMEs were negatively } \\
\text { affected by the Covid-19 pandemic in terms of sales, income, profits, and cash flow of } \\
\text { business owners. MSME actors must adapt by reducing production, and reducing the } \\
\text { number/hour of employees. More than that, product quality improvement and market } \\
\text { expansion are important things to do. The majority of MSMEs (82.9\%) in Indonesia } \\
\text { have been negatively affected by this pandemic. Various policy recommendations were } \\
\text { put forward to reduce the bad impact of the outbreak on MSMEs. }\end{array}$} \\
\hline Received Oct 09, 2021 & \\
\hline Revised Nov 03, 2021 & \\
\hline Accepted Nov 28, 2021 & \\
\hline $\begin{array}{l}\text { Keywords: } \\
\text { Covid-19, MSMEs, Indonesia, } \\
\text { Business Survival }\end{array}$ & \\
\hline
\end{tabular}

This is an open access article under the CC BY-SA license.

CorrespondingAuthor:

Edy Prayitno

Computer Information System Study Program, Sekolah Tinggi Manajemen Informatika dan Komputer

AKAKOM

Email: edyprayitno@akakom.ac.id

\section{INTRODUCTION}

The novel coronavirus (COVID-19) outbreak began in Wuhan, China, in December 2019, and the first known death was reported on January 11, 2020. The novel coronavirus spread rapidly, especially to Western Europe and the United States. On March 11, 2020, the World Health Organization declared a global pandemic ${ }^{11}$.

The outbreak of coronavirus disease-2019 (COVID-19) has severely affected national and global economies. Various enterprises are facing different issues with a certain degree of losses ${ }^{1}$.

According to the World Bank report on Global Economic Outlook (2020), the COVID-19 recession has the fastest downgrades in economic growth among all global recessions. It has adverse effects on nascent entrepreneurs, especially from developing countries where government support is limited. Lockdowns and moment control orders by authorities are the major factors affecting entrepreneurial activity ${ }^{2}$.

The major victims of COVID-19 outbreak are the micro, small \& medium-sized enterprises (MSMEs) because MSMEs, in comparison to large enterprises, usually do not possess sufficient resources, especially financial and managerial, and are not prepared for such disruptions likely to go longer than expected

The big impact of the Covid-19 pandemic that was felt by MSMEs was caused by the decline in the level of public consumption. Restrictions on activities in the midst of a pandemic put pressure on the economy, so people hold back their spending.

Based on the results of the Katadata Insight Center (KIC) survey conducted on 206 MSME actors in Greater Jakarta, the majority of MSMEs of $82.9 \%$ felt the negative impact of this pandemic and only $5.9 \%$ experienced positive 
growth. This pandemic condition has even affected 63.9\% of MSMEs experienced a decrease in turnover of more than $30 \%$. Only 3.8\% of MSMEs experienced an increase in turnover. Survey The KIC also shows that MSMEs are making a number of efforts to maintain their business conditions. They take a number of efficiency measures such as: reducing the production of goods/services, reducing working hours and the number of employees and sales/marketing channels. Even so, there are also MSMEs who take the opposite step, namely adding marketing channels as part of their survival strategy experienced a decrease in turnover of more than 30\%. Only 3.8\% of MSMEs experienced an increase in turnover. Survey of The KIC also shows that MSMEs are making a number of efforts to maintain their business conditions. They take a number of efficiency measures such as: reducing the production of goods/services, reducing working hours and the number of employees and sales/marketing channels. Even so, there are also MSMEs who take the opposite step, namely adding marketing channels as part of their survival strategy ${ }^{3}$.

One of the impacts of the COVID-19 pandemic is MSMEs in Indonesia. Based on data from the ministry of cooperatives which illustrates that 1,785 cooperatives and 163,713 Micro, Small and Medium Enterprises (MSMEs) are affected by the coronavirus pandemic (COVID-19). Most of the cooperatives affected by COVID-19 are engaged in daily necessities, while the MSME sector most affected is food and beverages ${ }^{4}$.

MSMEs must be saved from the impact of the Covid-19 pandemic, because the MSME sector is the backbone of the Indonesian economy, with a contribution of 57.24 percent of Indonesia's total gross domestic product (GDP). MSMEs are the most important pillars in the Indonesian economy. The number of MSMEs in Indonesia is 64.19 million, of which the composition of Micro and Small Enterprises is very dominant, namely 64.13 million or around $99.92 \%$ of the entire business sector ${ }^{5}$.

MSMEs are the backbone of the economy that provide income and job creation for many people in Indonesia. The Ministry of Cooperatives and Small and Medium Enterprises (UKM) noted that the MSME workforce was 119.6 million people in 2019 , equivalent to $96.92 \%$ of the total workforce in Indonesia ${ }^{6}$. MSEs are also critical to the circular economy, environmental protection, and social responsibility ${ }^{7}$.

\section{METHODS}

Overcoming the impact of the Covid-19 pandemic so that the business world, especially MSMEs, can survive, is carried out through several approaches of business survival, namely (1) capital; (2) business models; (3) market needs; and (4) organizational capability.

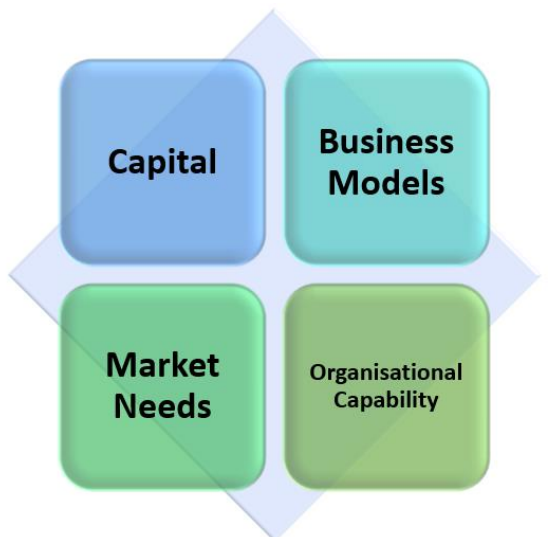

Fig 1. Business Survival

\section{Capital}

The classic problem of the business world facing a crisis, such as during the COVID-19 pandemic, is the lack of capital. The addition of capital is absolutely needed by MSMEs so that they can continue to run all their business processes properly. Additional capital can be in the form of grants or incentives from the government; business fund loans from banks or other financial institutions with easy terms and low interest rates. What is also important is the government's policy in favour of MSMEs, both related to capital and the protection of other MSMEs.

\section{Business Model}

The Covid-19 pandemic has made business people, including MSMEs aware, to think about other business models that are more appropriate to run. With advances in information and communication technology, new business models are available for MSMEs. Online marketing allows MSMEs to reach a much wider market, even globally, with the ease of transacting which is very helpful. 
International Journal of Social Science (IJSS)

Vol.1 Issue.4 December 2021, pp: 533-538

ISSN: 2798-3463 (Printed) | 2798-4079 (Online)

DOI: https://doi.org/10.53625/ijss.v1i4.1137

\section{Market Needs}

Understanding customer needs is an important thing that must be done to ensure that the product being sold is a product that can truly be a solution for consumers. For this reason, it is necessary to know the types of customer needs as a consideration.

\section{Organizational Capability}

Organizational advantage in competing can be achieved through adequate organizational capabilities ${ }^{8}$. Organizational capability as the ability to interact both socially and economically. Good capabilities are formed through good HR competencies as well ${ }^{9}$. Increasing organizational capability will directly improve business performance ${ }^{10}$.

\section{RESULT AND DISCUSSION Incentives}

One of the important solutions for MSME recovery is incentives for MSMEs through the central government's National Economic Recovery program in 2020 and continued in 2021. The result is that some of the informal sector and MSMEs can survive the impact of the Covid-19 pandemic. This means that it is not experiencing a very severe crisis compared to several large industries. In addition, this program is expected to help reduce the decrease in termination of employment rights for MSMEs. The reason is, based on BPS data (Central Bureau of Statistics) as of August 2020, there is the creation of new job opportunities with the addition of 760 thousand people opening businesses and an increase of 4.55 million informal workers ${ }^{11}$.

The Indonesian government has provided stimulus funds with the National Economic Recovery Program amounting to 123.4 trillion rupiah for the protection and support of MSMEs ${ }^{12}$.

In channeling funds or other support to MSMEs in particular, the government must ensure that support funds can be distributed quickly and on target. The problem faced today is the lack of integration of existing MSME data. In addition, the MSME support scheme through business loan interest subsidies also needs to receive more attention considering that there are still many MSMEs that are still unable to access banking services.

Regarding policy, the Indonesian government through the Ministry of Cooperatives and SMEs will prioritize policies for the MSME sector in national economic development. For this reason, the government has formulated 5 policy steps to solve the problems of MSMEs that have fallen in the midst of the pandemic.

These policies are, first, to encourage $98 \%$ of MSMEs to enter the new poor group in order to get social assistance. Second, postponement of installments and interest up to 6 months, because most MSMEs are experiencing financial problems. The government provides financing with subsidized taxes so that cash flow is resolved. Third, financing MSMEs and cooperatives through People's Business Credit. The fourth policy is to encourage government spending to be prioritized for MSME products. Fifth, MSMEs must innovate and adapt to new markets. The government encourages business actors, including MSMEs, to innovate and adapt to new markets. Currently, only 13 percent or 8 million MSME actors are connected online, so assistance, digital marketing training, and collaboration with the large business sector are needed ${ }^{13}$.

At this point, MSMEs will be strong if sufficient capital is available and is supported by government policies made to protect MSMEs.

\section{Business Model}

Changes in the business model can be made to adapt to technological developments and changes in consumer behaviour. Market behaviour has also shifted in making purchases, from buying at conventional stores to making transactions using digital technology facilities. The Covid-19 pandemic accelerates the awareness of MSME to immediately convert their business models from conventional to digital, without leaving the business model that has been implemented.

Several reasons why customers are starting to leave conventional shopping activities and switch to online purchasing transactions, namely (1) cost and time efficiency; (2) reduce fatigue; (3) avoid hassles; (4) competitive price; and (5) comfort factor ${ }^{4}$.

Cost and time efficiency are the main factors in conducting online transactions. By doing online transactions, it does not require a lot of costs, including transportation costs, parking fees, and accommodation costs which are one package with the transaction process. In terms of time, online shoppers do not need to spend special time doing shopping activities, especially spending a lot of time choosing and looking for goods, so they need strong physical strength.

Online purchase transactions free buyers from activities to visit shops, malls, or places to eat by spending a lot of energy, getting stuck in traffic jams and various problems that arise on the road. On the other hand, while shopping, 
they can continue to do activities at home or at work. Online shopping is freed from the hassle of carrying goods, even for large items, because all ordered items will be delivered to your home safely.

Online sellers are not charged special fees for shop rent, taxes, and other fees like conventional sellers, which in turn can make the selling price of goods cheaper than conventional ones. Finally, it is online shoppers who benefit from low prices. Especially if you get a voucher to get a discount or special price.

The convenience factor is certainly not in doubt, when shopping online we don't need to dress up, go out for shopping, even with a relaxed position we can do shopping activities, even shopping can also be in the middle of the night and holidays.

The presence of the online market brings many positive impacts, such as being closer to consumers/customers, quickly promoting or introducing products to the public, having no market boundaries to reach all corners of the world connected to the internet, and facilitating the right and fast service.

Digital transformation can help MSEs to manage public opinion, especially on environmental concerns, through visibility, connectivity, and management. When MSEs do not manage public opinion, these opinions may impact their image and credibility. MSEs with damaged reputations may also suffer from external losses and lose their benefits. Therefore, digitalization affects the credibility and competitive advantage of MSMEs ${ }^{14}$.

Exploring more media to expand customer base can be done as one way to promote products. Communication media with customers and exploring several options such as digital marketing to advertising can be done as product promotion media ${ }^{15}$.

\section{Market Needs}

The very rapid development of information technology is a dynamic in business that affects the increasing number of competitors that appear, making business people think about trying to evaluate the products being sold. Remove some products from the list for sale; modify the product creatively; adding new products to be sold is done to meet consumer needs.

Companies must continuously improve service quality and product quality in meeting consumer needs, so that when consumers come and order goods, the company can always fulfill and provide goods needed by consumers ${ }^{16}$.

An understanding of the varied needs and wants of buyers serves as a guide for the design of marketing strategies. Buyers usually show different preferences and priorities for products or services ${ }^{17}$.

\section{Organizational Capability}

Organizational capabilities need to identify organizational needs related to changes that occur, self-preparation for change. Organizational DNA must be designed to accommodate the social needs of digital customers

\section{CONCLUSION}

With sufficient capital and supported by government policies made to protect MSMEs; selecting the right business model adapted to the conditions of consumer behavior; knowing exactly the market needs according to the existing dynamics; and the readiness of the organization and all available resources, it is hoped that MSMEs will be able to survive, even rise from adversity due to the COVID-19 pandemic.

\section{REFERENCES}

[1] Shafi Mohsin, Liu Junrong, Ren Wenju, "Impact of COVID-19 pandemic on micro, small, and medium-sized Enterprises operating in Pakistan", Research in Globalization, 2 (2020) 100018.

[2] Global Economic Outlook. (2020). The global economic Outlook during the COVID19 pandemic: A changed World, 10.01.21 https://www.worldbank.org/en/news/ feature/2020/06/08/the-global-economic-outlook-during-the-covid-19pandemic-a-changed-world

[3] Kata Data Insight Center, "Digitalisasi UMKM di Tengah Pandemi Covid-19", 20 Juni 2020, https://katadata.co.id/umkm, accessed on May $18^{\text {th }} 2021$

[4] Amri Andi, "Dampak Covid-19 terhadap UMKM di Indonesia", JURNAL BRAND, Volume 2 No. 1, Juni 2020

[5] Bahtiar Rais Agil, "Dampak Pandemi Covid-19 terhadap Sektor Usaha Mikro, Kecil, dan Menengah serta", Info Singkat Vol. XIII, No.10/II/Puslit/Mei/2021

[6] Kata Data Insight Center, "Tenaga Kerja berasal dari UMKM", https://databoks.katadata.co.id/datapublish/2021/08/12/9692-tenaga-kerja-berasal-dari-umkm

[7] Katz-Gerro, T., López Sintas, J., 2019. Mapping circular economy activities in the European Union: patterns of implementation and their correlates in small and medium-sized enterprises. Bus. Strategy Environ. 28 (4), 485-496. doi:10.1002/ bse.2259. 
International Journal of Social Science (IJSS)

Vol.1 Issue.4 December 2021, pp: 533-538

ISSN: 2798-3463 (Printed) | 2798-4079 (Online)

[8] Pérez-de-Lema, D. G., E. Alfaro-Cortes, et al., "Strategy, Competitive Factors and Performance in Small and Medium Enterprise (SMEs)." African Journal of Business Management 6: 14 (2012)

[9] Liu, H., J. Hou, et al., "Entrepreneurial Orientation, Organizational Capability, and Competitive Advantage in Emerging Economies: Evidence From China." African Journal of Business Management 5: 12 (2011)

[10] Bungara Artaswinda Ayu, Rahardja Edy, Sugiarto J., "Pengaruh Kapabilitas Organisasi dan Orientasi Kewirausahaan terhadap Keunggulan Bersaing”, eprints.undip.ac.id (2017).

[11] Bahtiar Rais Agil , "Dampak Pandemi Covid-19 terhadap Sektor Usaha Mikro, Kecil, dan Menengah serta", Info Singkat Vol. XIII, No.10/II/Puslit/Mei/2021.

[12] Sari Nurmita, Rizki Muhammad, Solihati Keisha Dinya, "Dampak Stimulus Pemerintah untuk UMKM pada Era Pandemi Covid-19”, Jbest Jurnal of Business Administration Economics \& Entrepreneurship, Vol.3 No. 1 (2021)

[13] The Ministry of Cooperatives and SMEs, "5 Kebijakan atasi Masalah UMKM di Masa Pandemi" https://kemenkopukm.go.id/read/kemenkop-ukm-siapkan-5-langkah-kebijakan-atasi-masalah-umkm-di-masapandemi, June $19^{\text {th }} 2020$.

[14] Katz-Gerro, T., López Sintas, J., 2019. Mapping circular economy activities in the European Union: patterns of implementation and their correlates in small and medium-sized enterprises. Bus. Strategy Environ. 28 (4), 485-496. doi:10.1002/ bse. 2259

[15] Loo, W. T., Kee, D. M. H., Har, C. W., Loo, C. L., Hau, W. M., Sara, A., Ekta, B., 2020, The Success Factors: A Study of Amway in Malaysia, Internasional Journal of Tourism \& Hospitality in Asia Pasific, Vol 3, No 1 .

[16] Widharta Willy Pratama, Sugiharto Sugiono, "Penyususnan Strategi dan Sistem Penjualan dalam rangka Meningkatkan Penjualan Toko Damai”, Jurnal manajemen pemasaran PETRA Vol. 2, No. 1, (2013) 1-15

[17] Dayat M., "Strategi Pemasaran dan Optimalisasi Bauran Pemasaran dalam Merebut Calon Konsumen", Jurnal Mu'allim Vol. 1 No. July $2^{\text {nd }} 2019$ 
